\title{
Culture Conditions for Production of 2-1- $\beta$-D-Fructan- fructanohydrolase in Solid Culturing on Chicory (Cichorium intybus) Roots
}

\author{
Ashok Pandey ${ }^{* 1}$, Poomarathil Kavita and Ponniah Selvakumar \\ Biotechnology Division, Regional Research Laboratory, Council of Scientific and Industrial Research (CSIR), \\ Trivandrum-695 019, India; ${ }^{l}$ Present address- Laboratorio de Processos Biotecnologicos, Departamento de Engenharia \\ Quimica, Universidade Federal do Parana, CEP 81531-970 Curitiba-PR, Brazil
}

\begin{abstract}
Investigations were carried out to optimize the culture conditions for the production of $\beta$-D-fructanfructanohydrolase by an indigenously isolated bacterial culture of Staphylococcus sp. RRL8. Experiments were carried out in solid culturing using chicory roots (powdered) as the source of carbon, which was supplemented, with corn steep liquor and potassium dihydrogen phosphate. A number of process parameters, like period of cultivation, initial moisture content in the substrate and temperature of incubation were optimized. Maximum extra-cellular enzyme was produced when fermentation was carried out at $30^{\circ} \mathrm{C}$ for $24 \mathrm{~h}$ using chicory roots with $60 \%$ initial moisture. Supplementation of the substrate with additional carbon source (except with sucrose) resulted decreased enzyme titres, which indicated that the strain was partially depressive. Addition of external nitrogen sources (in addition to corn steep liquor) also failed to stimulate enzyme formation; rather exerted harmful impact on bacterial culture of Staphylococcus sp. RRL8.
\end{abstract}

Key words: Fructan-fructanohydrolase, Inulinase, Solid state fermentation, Staphylococcus sp., Chicory

\section{INTRODUCTION}

The microbial enzyme, 2-1- $\beta$-D-fructanfructanohydrolase (inulinase, $\mathrm{EC}-3.2 .1 .7$ ) hydrolyses the plant polymer inulin into practically pure fructose. As such, inulinase offers interesting perspectives in view of the growing need for production of pure fructose syrups or may present an alternative way to produce the so called "Ultra High FructoseGlucose Syrups" (UHFGS) - not from starch, but from inulin. Conventional fructose production from starch needs at least three enzymatic steps, including $\alpha$-amylase, amyloglucosidase and glucose isomerase action, yielding maximum only $\sim 45 \%$ fructose solutions at the best. Fructose formation from inulin is a single enzymatic step reaction and yields up to
95\% fructose is easily obtainable. Fructose is more soluble than sucrose, displays a greater sweetening power, and can mask the bitter 'aftertaste' of saccharin. Another timely application of inulinase consists of the direct fermentation of inulin into ethanol, using a yeast culture having inulinase activity also.

Chemical (acid) hydrolysis of inulin to fructose displays several drawbacks. Acid hydrolysis always resulted in an undesirable colouring of the inulin hydrolyse. Changes in taste and aroma are minimal upon enzymatic hydrolysis. Acid hydrolysis also results in formation of $~ 5 \%$ difructose anhydride, which has practically no sweetening properties. This compound can not be further hydrolysed enzymatically into fructose. Based on this, a forced interest has developed

* Author for correspondence 
towards the microbial inulinase enzyme and its production. (Vandamme et al, 1981).

Solid-state Fermentation (SSF) is generally defined as the growth of the micro-organisms on moist solid substrates in the absence or near absence of free water (Pandey 1992a, 1994). Solid substrates employed in SSF processes are insoluble in water and act as a source of carbon, nitrogen, minerals as well as growth factors. They have the capacity to absorb water and it is this water that meets the vital requirement of water by micro-organisms. The solid substrate also provides anchorage to the microbial cells.

Literature survey showed that although a number of microbial cultures belonging to yeast and fungi have been used for the production of inulinases, not much work has been done on bacterial inulinases (Pandey et al. 1998a). In the present study, we report the production of extra-cellular inulinase in solid cultures by a strain of Staphylococcus sp.

\section{MATERIALS AND METHODS}

Micro-organism: A bacterial strain of Staphylococcus sp. RRL8, a RRL isolates (Selvakumar and Pandey, 1998 a, b), was used for this study. It was maintained on Yeast extractPeptone-Inulin agar, sub-cultured fortnightly and stored at $4^{\circ} \mathrm{C}$.

Inoculum preparation: The medium contained $(\mathrm{g} / \mathrm{L})$ : Yeast extract 10, Bacto peptone 20 and inulin 10 as a sole carbon source (pH 6.5). It was autoclaved at $121^{\circ} \mathrm{C}$ for $20 \mathrm{~min}$. A loopful of cells were transferred into $250-\mathrm{ml}$ conical flask containing $20-\mathrm{ml}$ medium. The culture was incubated at $30^{\circ} \mathrm{C}$ for $24 \mathrm{~h}$ on a rotary shaker operating at $150 \mathrm{rpm}$.

Solid state fermentation: Chicory root was procured from the local market, washed well, chopped into small pieces and dried at $80^{\circ} \mathrm{C}$ in a hot air oven. The dried root was powdered and used as solid substrate. A weighed quantity (5 g, dry wt.) of chicory root powder was supplemented with $1.0 \mathrm{~g}$ of corn steep liquor (Sigma, USA) and $0.5 \mathrm{~g}$ of $\mathrm{KH}_{2} \mathrm{PO}_{4}$ and mixed well. Initial $\mathrm{pH}$ and moisture of the substrate were set at 5.5 and $50 \%$, respectively. The wet substrate was autoclaved at 15 psi for $20 \mathrm{~min}$.

Fermentation was carried out with 7.5-g moist substrate in Petri dish (internal diameter, $9.0 \mathrm{~cm}$ ). Each Petri dish was inoculated with 5\% (v/w) cell suspension and was incubated at $30^{\circ} \mathrm{C}$ for stipulated period of time. Petri dishes were withdrawn in duplicate as samples. Results reported are the average of three sets of the experiments.

Extraction of enzyme: A weighed quantity ( $5 \mathrm{~g}$ ) of the fermented matter was treated with $50 \mathrm{ml}-$ distilled water and mixed thoroughly on a magnetic stirrer for $30 \mathrm{~min}$. The whole contents were filtered through muslin cloth. The residue was again treated with another $50 \mathrm{ml}$ of distilled water, mixed in the same way and filtered. Both the filtrates were combined.

Enzyme assay: Enzyme assay was carried out by the following procedure. To $2-\mathrm{ml} 0.2 \%$ inulin, 2$\mathrm{ml} 0.01 \mathrm{~mol} / \mathrm{L}$ acetate buffer ( $\mathrm{pH} 4.6$ ) was added. Culture filtrate $(0.5-\mathrm{ml}$, diluted, if necessary) were added to this and incubated at $50^{\circ} \mathrm{C}$ for $20 \mathrm{~min}$. After incubation, the tubes were kept in a boiling water bath for $10 \mathrm{~min}$. to inactivate the enzyme and then cooled to room temperature. The reaction mixture was assayed for reducing sugars as fructose by DNS method (Miller, 1959) by reading the absorbance at $575 \mathrm{~nm}$ on a spectrophotometer (Shimadzu 160A, Japan). Calibration curve was prepared with a fructose solution of known strength. Blanks were run simultaneously with the enzyme and substrate solutions. One unit of inulinase activity was defined as the amount of enzyme, which produced one micro mol of fructose under the assay conditions. 
Moisture analysis: Moisture content of the solid substrate was determined by drying it at $80^{\circ} \mathrm{C}$ for $24 \mathrm{~h}$.

\section{RESULTS}

Fig.1 shows inulinase production on chicory root powder by Staphylococcus sp. RRL8 over a period of $72 \mathrm{~h}$ to determine the optimal period of cultivation. Fermentation was carried out at $30^{\circ} \mathrm{C}$

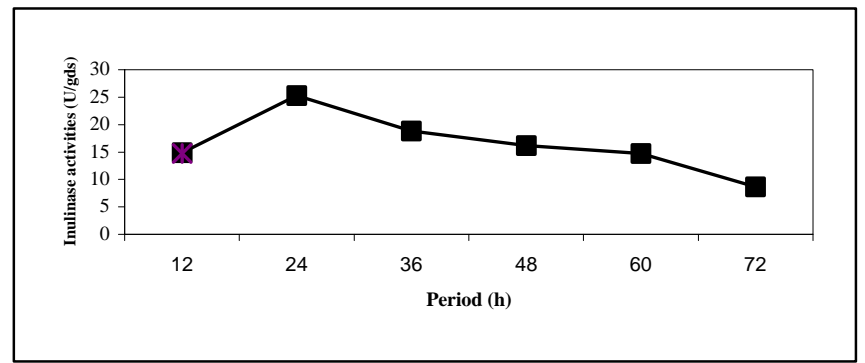

Fig. 1. Inulinase synthesis in SSF (72h)

and samples were withdrawn each $12 \mathrm{~h}$. Evidently, maximum accumulation of extracellular inulinase in the fermentation medium by the bacterial strain occurred at $24 \mathrm{~h}$, which was $25.27 \mathrm{U} /$ gram dry (fermented) substrate (gds). With increased time of cultivation, there was decrease in enzyme titres and at $72 \mathrm{~h}$, enzyme activities were only about $30 \%$ of the optimal level. Table 1 shows the $\mathrm{pH}$ of the substrate.

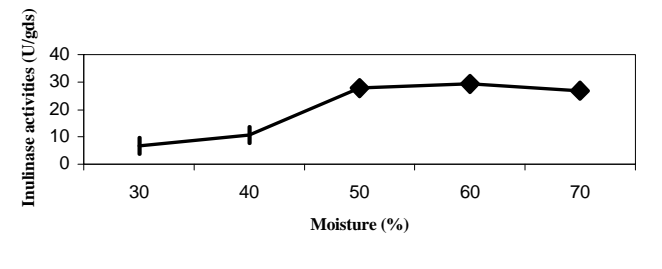

Fig. 2. Effect of substrate moisture on inulinase synthesis in SSF

In order to study the effect of initial substrate moisture on enzyme production by the culture, five different initial moisture level, viz. 30, $40,50,60$, and $70 \%$ were established in the substrate. All the Petri dishes were cultivated for $24 \mathrm{~h}$ at $30^{\circ} \mathrm{C}$ and the results obtained are presented in Fig.2. As is evident, maximum extra-cellular enzyme activity was obtained with the substrate having initial moisture as $60 \%(29.86 \mathrm{U} / \mathrm{gds})$. At $50 \%$ moisture level too reasonably good amounts of the enzymes were produced.

Fig. 3 shows the effect of temperature of incubation on extra-cellular inulinase synthesis by the bacterial strain. Four different incubation temperatures, viz. 25, 30, of 35 and $40^{\circ} \mathrm{C}$ were tested. Fermentation was carried out for $24 \mathrm{~h}$ with the substrate having $60 \%$ initial moisture. Maximum inulinase activity (27.99 $\mathrm{U} / \mathrm{gds}$ ) was observed at $30^{\circ} \mathrm{C}$. Higher incubation temperature resulted decreased yields of the enzyme.

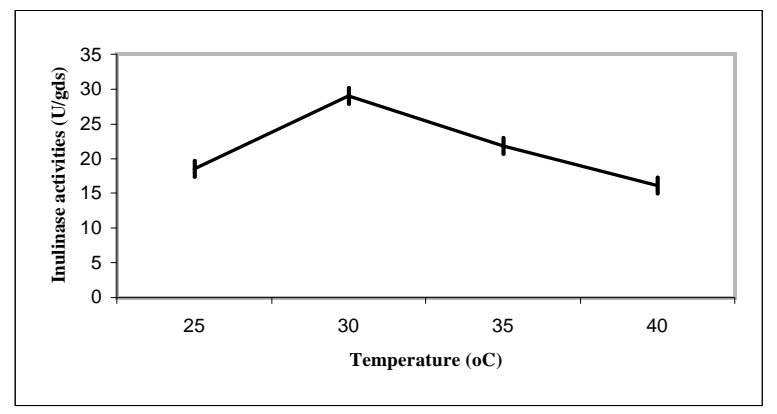

Fig. 3. Effect of incubation temperature on inulinase synthesis in SSF

\section{Effect of addition of carbon sources on inulinase production}

Experiments were also carried out to study the effect of addition of different carbon sources in the fermentation medium on the growth and activity of the bacterial strain. Fermentation was carried out at $30^{\circ} \mathrm{C}$ with the substrate having $60 \%$ initial moisture for $48 \mathrm{~h}$ and samples were withdrawn at $24 \mathrm{~h}$. Six different carbon sources, glucose, sucrose, maltose, starch, glycerol and lactose, at $1.0 \%(\mathrm{w} / \mathrm{w})$ concentration were tested individually. Results obtained are shown in the Table 2. While glucose, maltose, starch, glycerol and lactose inhibited the bacterial activity of enzyme synthesis, sucrose resulted a significant increase in the inulinase titres. Highest enzyme activities were $37.74 \mathrm{U} / \mathrm{gds}$ after $24 \mathrm{~h}$ of fermentation. However, there was a marked deterioration in the enzyme yields on longer cultivation period (cf. Table 2). 
Table 1. $\mathrm{pH}$ profile of fermenting substrate during the course of solid state fermentation

\begin{tabular}{lrrrrrrr}
\hline Period (h) & 0 & 12 & 24 & 36 & 48 & 60 & 72 \\
$\mathrm{pH}$ & 5.50 & 5.52 & 5.56 & 5.57 & 5.78 & 5.87 & 5.89 \\
\hline
\end{tabular}

Table 2. Effect of carbon sources on inulinase synthesis in SSF

\begin{tabular}{llc}
\hline C-source & \multicolumn{2}{l}{ Inulinase activity (U/gds) } \\
& $24 \mathrm{~h}$ & $48 \mathrm{~h}$ \\
\hline Glucose & 23.30 & 21.92 \\
Sucrose & 37.74 & 23.49 \\
Maltose & 19.50 & 18.03 \\
Lactose & 28.31 & 22.95 \\
Starch & 20.10 & 19.41 \\
Glycerol & 25.98 & 20.56 \\
Control & 29.31 & 17.10 \\
\hline
\end{tabular}

Effect of addition of nitrogen sources on inulinase production

Studies were performed to test the efficacy of different organic and inorganic nitrogen sources on enzyme synthesis by Staphylococcus sp. when added in the fermenting medium. Fermentation was carried out at $30^{\circ} \mathrm{C}$ with initial moisture of substrate as $60 \%$ for $48 \mathrm{~h}$. Samples were withdrawn at $24 \mathrm{~h}$. The results are recorded in Fig. 4. Six nitrogenous sources of organic and

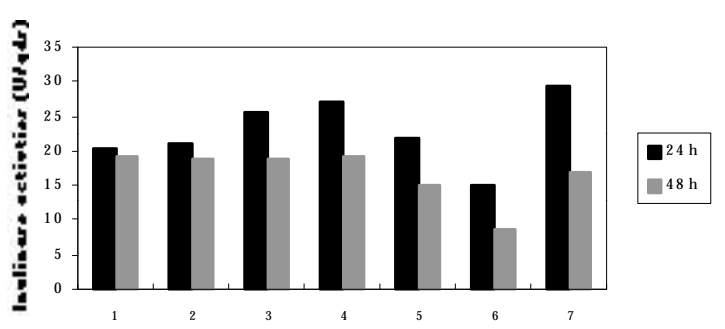

Fig. 4. Effect of nitrogen Sogurce on in inulinase synthesis in SSF

inorganic nature, viz. $\mathrm{NaNO}_{3}$ (1), $\mathrm{NH}_{4} \mathrm{Cl}$ (2), $\left(\mathrm{NH}_{4}\right)_{2} \mathrm{SO}_{4}$ (3), urea (4), beef extract (5), and yeast extract (6) at $0.5 \%(\mathrm{w} / \mathrm{w})$ concentration were added individually in the medium. As is evident from the Fig. 4, none of the tested compound proved useful for bacterial activity of inulinase synthesis as in all cases the enzyme titres was less than the control experiment (7). Among all the compounds, while urea proved to be the least harmful, yeast extract exerted most harmful impact with the result that inulinase activities were reduced to almost $50 \%$ of the control experiment.

\section{DISCUSSION}

Solid state fermentation is being increasingly used in microbial processes, and microbialenzyme production is an area where SSF has particularly established its credential (Pandey et al. 1998b). There are a number of process parameters, which need to be optimized for any individual strain for the production of a given enzyme. Among these, cultivation period, moisture of the substrate, and temperature of incubation are the critical factors. In the present studies, a period of $24 \mathrm{~h}$ was found to be optimum for enzyme synthesis by the bacterial culture; cultivation beyond this period resulted loss of the product. Inulinase is a primary metabolite, which is secreted by the microorganism during its growth phase.

Moisture has been termed as one of the most important aspect, which controls microbial growth and activity in SSF (Pandey, 1992b). For this reason, generally moulds are the preferred choice in SSF. But in the present studies, we successfully cultivated a bacterial strain of Staphylococcus sp. RRL8, which produced maximum enzyme with a substrate having $60 \%$ initial moisture. Low substrate moistures in SSF resulted in suboptimal product formation due to the reduced mass transfer process such as diffusion of solutesand gas to cell during the fermentation. The decrease in moisture level is advantageous since the chances of contamination of fermentation medium are reduced. 
Temperature is yet another important aspect, which affects SSF processes largely. It was reported that during microbial cultivation in SSF, temperature of fermenting bed risen which exerted harmful impact on the microbial strain (Pandey, 1990). In the present studies, $30^{\circ} \mathrm{C}$ temperature proved to be the best for inulinase synthesis by microbial culture. Higher temperatures affected bacterial activity harmfully. During SSF, a large amount of heat is generated which is directly proportional to the metabolic activities of the micro-organisms (Mudgett, 1986). In the early phases of SSF, the temperature and concentration of oxygen remain uniform throughout the substrate bed but as the fermentation progresses, oxygen transfer takes place resulting the generation of heat (Pandey, 1994).

For the optimum growth of micro-organisms, apart from above physical parameters, a number of other factors (chemical and biochemical parameters) and some times, inducers are required to be added in the formulation of growth and/or fermentation medium. With this view, we added a number of carbon and nitrogen sources in the fermentation medium to see their impact. As is apparent from the Table 2 and Fig. 4, the added compounds largely were unfavourable for the growth and activity of the bacterial culture. All the carbon sources, except sucrose, retarded enzyme synthesis, which indicated that the strain was probably repressive. All the nitrogenous compounds, irrespective of their nature, organic or inorganic, also retarded enzyme synthesis which indicated that with the addition of corn steep liquor, a reasonably good $\mathrm{C} / \mathrm{N}$ ratio was established and no further nitrogen was needed in the medium. When additional nitrogen was supplemented, it resulted imbalanced $\mathrm{C} / \mathrm{N}$ ratio, which interfered with the bacterial activity of inulinase synthesis.

\section{ACKNOWLEDGEMENTS}

P. Kavita thanks the Director, RRL for providing lab facilities for doing her Master's dissertation work. She also thanks Prof. P. Bisen, Head of Microbiology Department, Barkatullah University, Bhopal for allowing her to do the project work at RRL, Trivandrum. A research grant from the Department of Biotechnology, New Delhi is gratefully acknowledged. Thanks are due to Professor Carlos R. Soccol for helping in preparation of Portuguese Resume. We also thank to Mr. Radjiskumar Mohan, UFPR for his help in the preparation of the manuscript.

\section{RESUMO}

Estudos foram realizados com o objetivo de otimizar as condições de cultura para a produção de $\beta$-D-fructan-fructanohydrolase (inulinase) com uma cepa selvagem de Estafilococos sp. RRL8. Os experimento foram realizados em meio sólido utilizando raiz de chicória moída como única fonte de carbono e suplementada com licor de milho e $\mathrm{KH}_{2} \mathrm{PO}_{4}$ p. Uma certo número de parâmetros, tais como tempo de cultivo, umidade inicial e temperatura de incubação foram otimizadas. A produção máxima de enzima extracelular foi obtida quando a fermentação foi realizada à temperatura de $30^{\circ} \mathrm{C}$ por um período de 24 horas e um teor umidade de $60 \%$. A suplementação do substrato com uma fonte de carbono adicional (exceto com sacarose) resultou no decréscimo da produção de enzima, o que indica que a cepa foi parcialmente depressiva. A adição de uma fonte de nitrogênio externa também não resultou em maior de produção da enzima, ao contrario um impacto nocivo na cultura de Estafilococos sp. RRL8. 


\section{REFERENCES}

Miller, G.L. (1959), Use of dinitrosalicylic acid reagent for determination of reducing sugars.Anal. Chem., 31, 426-428.

Mudgett, R. E. (1986), In: Manual of Industrial Microbiol. Biotechnol, eds. A. L. Demain \& N.A Solomon, American Society for Microbiology, Washington, D.C. Pp, 66-83.

Pandey, Ashok (1990), Improvements in solid state fermentation for glucoamylase production. Biol. Wastes, 34, 11-19.

Pandey, Ashok (1992a), Recent process developments in solid state fermentation. Process Biochem. 27, 109-117.

Pandey, Ashok (1992b), Production of starch saccharifying enzyme in solid cultures. Starch/Starke, 39, 75-77.

Pandey, Ashok (1994), Solid state fermentation: An overview. In: Solid State Fermentation (Ed.) Ashok Pandey, Wiley Eastern Ltd., New Delhi. Pp. 3-10.

Pandey, Ashok; Soccol, C. R.; Selvakumar, P; Soccol, V. T; Krieger, N. \& Fontana, J. D. (1998a), Recent developments in microbial inulinases-Its production, properties and industrial applications. Appl. Biochem. Biotechnol. (Submitted).
Pandey, Ashok; Selvakumar, P; Soccol, C. R. \& Nigam, P. (1998b), Solid state fermentation for the production of industrial enzymes. Curr. Sci., In press.

Selvakumar, P. \& Pandey, Ashok (1998a), Isolation and characterization of inulinase producing cultures from rhizosphere of dahlia. J. Sci. Ind. Res., 57, (In Press).

Selvakumar, P. \& Pandey, Ashok (1998b), Comparative studies on inulinase synthesis by Staphylococcus sp. and Kluyveromyces marxianus in submerged cultures. Biores.Technol., Accepted.

Vandamme, E. J; Delaporte, A; Deo Vocht, M. \& Van Hoe, L. (1981) Abh. Akad. Wiss. DDR, Akademic-Verlag, Berlin. 193-208.

Received: August 21, 1998; Revised: August 21, 1998; Accepted: September 02, 1998. 